\title{
Keratin, Type II Cytoskeletal 7
}

National Cancer Institute

\section{Source}

National Cancer Institute. Keratin, Type II Cytoskeletal 7. NCI Thesaurus. Code C96446.

Keratin, type Il cytoskeletal 7 (469 aa, $\sim 51 \mathrm{kDa}$ ) is encoded by the human KRT7 gene.

This protein plays a role in DNA replication and cytoskeleton modeling. 